\title{
Preface and acknowledgments: Introspection and Ritorno al Passato
}

This book is about resolving the crisis in research. I am addressing urgent topics in most academic disciplines, but with a focus on social sciences. However, my experiences are mostly from management research, and most of my examples are thus related to management scholarship. The book builds on reflections about my experiences from the past, but returning to the past may be a good starting point for setting the direction for the future. Ritorno al passato is a restaurant in Rome. I used this restaurant as my office during the seven years in which I worked in Rome monthly. I have many positive memories from this restaurant. There, I felt that I was at the center of the world. I was living in my busy reality at the beginning of the twenty-first century, while my table and chair in the restaurant were located in such a way that I could see directly into the Pantheon. Two thousand years ago the Pantheon was the center of the world. The dome of the Pantheon was the largest dome in the world for 1300 years, and is still the largest unsupported dome. Pantheon means "honor all gods," and the Pantheon was completed in its present shape by the emperor Hadrian, probably dedicated about 126 AD. This was the golden age of the Roman empire, which the Pantheon represented. It was a true testament to the might and glory of a worldly government. The Pantheon represents a true cultural revolution.

In my office in front of the Pantheon, I saw the movements of politicians, business people, tourists, homeless people, and all the colleagues and friends that came to see me. I had time for reflection and writing, discussions with strangers, sharing experiences with my students and friends, and experiencing the joy of a good wine. In Ritorno al passato I was able to reflect on what matters most, about Socrates and dialogues, and the importance of the heart and passion. I am thus dedicating this book to Ritorno al passato even though I also argue this book is about creating a new game. This game was illustrated through the sharing, communal, open, and impact-driven philosophy that was formulated as I was sitting in my office in front of the Pantheon. 
I am committed to resolving the crisis in research through my scholarship. My contribution, and this book, are influenced by introspection. In practice this means that I am interpreting the reality through reflecting on my previous experiences. They are shaping my understandings and position. I thus write this book in a personal way with an "I form." However, my experiences and my passions become more evident as we move from Part I to Part II. I am writing about something I believe in and that is very close to my heart.

This book is a spinoff from and a development of an ERC Advanced grant proposal I submitted in 2017, and it leans on my research trajectory. The book is the result of a journey of at least 40 years, and I use examples that have a history dating back more than 40 years. In this period, I have integrated research, practice, and policymaking. Johanna Degen has been my tutor and inspirational partner in introspection. Hannah Möltner and Alessandra Rigolini stimulated me to reflect on experiences that led to a "sharing philosophy" that is communal, open, and impact-driven. I am very thankful for this inspiration.

My initial research education came in the 1970s, and throughout most of the 1980s I worked in business. In 1989, I returned to academia. I was not a scout as a child, but I often describe my values as those of a scout. Justice and fairness are important, and I have always been willing to fight for what I believe in. Sometimes, this has brought me trouble, and I got many bruises. I have also accepted that I cannot be friends with everybody or expect that everybody will like me. I have enemies, and I am sure that not everybody will be happy with what I write in this book. Nevertheless, the reason why I write it is that I believe in it and want to do something that is good for business, for society, and for academia.

Twice in the 1990s I was taken to hospital by ambulance. In both cases the outcome could have been fatal. I learned from these experiences that "life is too short to drink bad wine," that is, that I do not have time to do things which are not important. Further, I do not have time to spend with people that simply take my energy. I should spend time with people who give energy. This book reflects both aspects - that of importance and that of people.

For many years I persistently voiced an overall criticism of the "publish or perish" culture in academia. I was thinking of myself along the lines of Cato in the old Roman senate. He persistently advocated for the total destruction of Cartago, and repeatedly stated "Carthago delenda est" (Cartago must be destroyed). The core message in this book is something that I have communicated regularly and repeatedly since 
the mid-1990s. The "publish or perish" culture, with its "lamp" and "hammer" syndromes, is moving us away from doing important, relevant, and venturesome research (Huse, 1996). I have had an interesting academic journey since the mid-1990s, but I have been like Cato, and I am still repeating it: "Carthago delenda est." That is what this book is about.

Over the years, I developed increasing recognition as a scholar. My stubborn insistence that Cartago must be destroyed (that we must fight the "publish or perish" culture) has given me many bruises, but also led to many experiences and lessons. I have also had opportunities to influence. I was a member of the board of governors of the International Association of Business Society (IABS) 1966-99 and President of the European Academy of Management (EURAM - presented in Chapter 4) 2010-12, and while writing this book I was elected as a member of the board of governors at the Academy of Management (AOM - presented in Chapter 3) for the 2019-22 period. The Norefjell workshops (Chapter 6), the Witten seminars (Chapter 7), and the Women on Board Cruise Workshops (Chapter 8) have also given me opportunities to influence.

On the practitioner side, for example, I was President of the National Association of Directors in Norway 1997-2000 and a member of the Catalyst Europe advisory board 2009-14. At the same time, I held full- or part-time positions at academic institutions in several countries. I have been living and working in the intersection between research and practice, but always bringing my scholarly identity with me. These experiences contributed to framing and writing this book. In practice, this means that I do not only criticize; I also bring suggestions for solutions to the table.

In 2018, I had a book published in the Cambridge Elements series (Huse, 2018a). That was a provocative book about value-creating boards. However, Amedeo Pugliese challenged me to be even more provocative, also considering methods. The 2018 book was not about methods, but this book is about method. Amedeo made me channel my methodological sentiments into the present book. Several friends and colleagues have contributed to this book with ideas about a "sharing philosophy." Some have given comments on the whole book, others on parts of it or possible spin-offs of the book. In addition to those previously mentioned, I will highlight in particular Thomas Clarke, Jonas Gabrielsson, Juliane Göke, Wafa Khlif, and Sibel Yamak. For discussion and encouragement, thanks are also due to Thomas Durand, Patricia Gabaldon, Benson Honig, Silke Machold, and Stella Nkomo, but also to many others whom I have met 
over the years who shared my sentiments. Discussions with Alessandro Zattoni over many years have been important.

One spin-off from the book is the paper "What matters most for our scholarly community: Reflections from former AOM presidents" (Huse, 2019). The AOM presidents from 1994 to 2018 were given the opportunity to comment on this paper, which reflects on Chapter 3 of this book. About half of them offered important comments, in particular Jean Bartunek, Thomas Lee, Andrew van de Ven, and Jim Walsh. My colleague here in Oslo, Susann Gjerde, also gave me important support in writing that paper. Thanks to all of them.

Thanks to Francine O'Sullivan, who immediately saw the potential in this book and encouraged me to have it published with Edward Elgar. Thanks to all those that have formed me on the journey leading to this book. Thanks for all the business people and policy activists that have joined me using action research and the Champagne method. Thanks to all my students that have patiently allowed me to experiment with, and have learned to apply, anthroposophical and Humboldtian teaching philosophy. Finally, thanks to all those, including colleagues, friends, and particularly my wife Cathinca, that have borne with me as all of my available time was taken up with writing this book.

Morten Huse

Oslo, September 2019 
Morten Huse - 9781789906646

Downloaded from PubFactory at $04 / 26 / 2023$ 08:40:58AM

via free access 